Estrangement, Alienation and Exploitation 


\title{
Estrangement, Alienation and Exploitation
}

\author{
A Sociological Approach \\ to Historical Materialism
}

JOHN TORRANCE

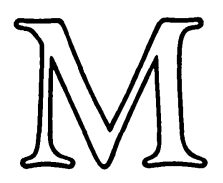




\section{(C) John Torrance 1977}

Softcover reprint of the hardcover 1st edition 1977 978-o-333-1985o-6

All rights reserved. No part of this publication may be eproduced or transmitted, in any form or by any means, without permission

First published 1977 by

THE MACMILLAN PRESS LTD

London and Basingstoke

Associated companies in New York

Dublin Melbourne Johannesburg and Madras

ISBN 978-1-349-03064-4 ISBN 978-1-349-03062-o (eBook)

DOI 10.1007/978-1-349-03062-o

This book is sold subject

to the standard conditions

of the Net Book Agreement 
TO CHARITI

In love and gratitude for her encouragement and forbearance, and for her devoted assistance in preparing the manuscript 


\section{Contents}

Acknowledgments $\quad$ ix

Introduction $\quad$ xi

PART I ESTRANGEMENT AND ALIENATION IN PRESOCIOLOGICAL THOUGHT

I Estrangement and Alienation in Ideology 3

2 Estrangement and Alienation in The Phenomenology of Mind 21

3 Marx's Feuerbachian Metaphysics: the Self-Estrangement of Man

PART II ESTRANGEMENT AS A SOCIOLOGICAL CONCEPT

4 Marx's Hegelian Sociology: Statics and Dynamics of Estrangement

5 Estrangement and Solidarity in Sociological Theory

PART III ALIENATION AS A SOCIOLOGICAL CONCEPT

6 What is Property?

7 Alienation and Appropriation

PART IV ESTRANGEMENT AND ALIENATION IN HISTORICAL MATERIALISM: TOWARDS A SOCIOLOGICAL RECONSTRUCTION

8 Exploitation

9 Possession, Production and Society

Notes

Works cited in the text 


\section{Acknowledgments}

I should like to thank the Principal and Fellows of Hertford College for the two spells of leave in which this book was conceived and then written. During the first of these the Warden and Fellows of Nuffield College kindly gave me the benefits of Associate Membership. During the second I was Visiting Lecturer at the University of Auckland, New Zealand, and I am especially grateful to Professor David Pitt and his colleagues in the Sociology Department for providing the most favourable conditions for academic production.

I and the publishers also wish to thank the following who have kindly given permission for the use of copyright material: George Allen \& Unwin (Publishers) Ltd, for the excerpts from Capital, Vol. I, by Karl Marx, translated by E. \& C. Paul and George Allen \& Unwin (Publishers) Ltd (Humanities Press Ltd), for the excerpts from The Phenomenology of Mind by G. W.F. Hegel, translated by J. Baillie; Basil Blackwell \& Mott Ltd, for the excerpts from Early Texts by Karl Marx, translated and edited by D. McLellan; Lawrence \& Wishart Ltd, for the excerpts from The German Ideology by Karl Marx and F. Engels, translated by R. Pascal et al.; for the excerpts from Economic and Philosophical Manuscripts by Karl Marx, translated by M. Milligan and D. J. Struik, and for the excerpts from Theories of Surplus Value, Part III, by Karl Marx, translated by E. Burns; and Penguin Books Ltd and Random House Inc., for the excerpts from Grundrisse: Foundations of the Critique of Political Economy by Karl Marx, translated by Martin Nicolaus (1973), translation copyright (C) Martin Nicolaus, 1973 .

Hertford College, Oxford

J. T.

August 1976 


\section{Introduction}

Commentators on Marx have always noted that his concept of alienation contains two semantic elements, alienation in the sense of renunciation or relinquishment, and alienation in the sense of estrangement. Few, however, have pressed this distinction very far, being content with remarking that in both Hegel and Marx - the watershed from which alienation theory descends into modern thought - the two senses are closely linked, if not conflated. Since this may be a reason why the idea of alienation, despite all that has been written about it, remains unclear and far from univocal, the present study will attempt the opposite approach. It will maintain a sharp distinction between the two senses of alienation, and seek the theoretical significances of each, and of their conjunction, primarily in their divergence and heterogeneity. The aim will be to clarify the theoretical basis of Marxism, while emphasising its sociological character, and to supply sociological theory in general with some missing conceptual elements. ${ }^{1}$

Writers in English and French have perhaps been more apt than Germans to use 'alienation' as an unanalysed compound. If so, this is no doubt because, in these languages, the word carries both of the two meanings which, in German, correspond to Entäusserung and Entfremdung, the terms actually used by Hegel and Marx. Since the ease with which these two quite different meanings can be conveyed in translation by a single homonym has encouraged the mistaken idea that their close conjunction in Hegel and Marx is in fact an inextricable fusion, let us begin by sorting out the two notions involved, irrespective of language. For this purpose, the term 'alienation' itself will henceforward be restricted to one of these, and the other will be denoted by 'estrangement'.

'Alienation' in this restricted sense (Entäusserung, entäussern, veräussern) refers to the renunciation or relinquishment of possession, or of a claim to something, or of a liberty or power to do some action - usually, but not necessarily, in favour of some other person or persons specified or unspecified. It is not surprising that this sounds like a lawyer's definition, for legal contexts are where the word is most often found. Nevertheless, it is not, or need not be, a 'legal concept'. It denotes simply a type of social action, or social practice: an action which has the effect of altering a social relationship previously existing between a person and any others affected by the claims or powers relinquished. So, although the word may come to have special application in law or commerce or politics, the primary 
location of the idea is in general reference to social life. If it is to be a scholarly or scientific concept at all, therefore, it is, at least potentially, a sociological concept. A possible usefulness, in this connection, is its high level of abstraction. For it includes all voluntary acts of disposal of claims - whether by sacrifice, gift, exchange, bequest, abandonment or any other action-and, arguably, compulsory acts of surrender and abdication as well. At this level, 'alienation' functions as a correlative of 'appropriation', which includes any taking possession or assumption of powers not previously held - whether with consent or, if we are prepared to define 'expropriation' as 'forcible appropriation', by compulsion. Together, alienation and appropriation, without any undue stretching of their everyday meanings, can therefore be used to describe a complete transfer of claims from one party to another, representing the beginning and end of a social process and the two poles of a social relationship. The parties concerned may themselves be individuals or collectivities. Further consideration of the sociological bearings of these terms will be left for later; there are, however, some extensions of the social usage of alienation which deserve mention here.

Obviously, persons may alienate their own autonomy, partially or wholly, so that we may have to speak of 'self-alienation' in this sense. Furthermore, like most other ideas having a primarily social reference, alienation may be transposed into various contexts where the relationship is internalised to the psyche, or exists only in an imaginary or figurative way. Thus, to take a trivial example, an individual may renounce the liberty to smoke and simultaneously assume, as his own moral censor, power to prevent himself from smoking. Such a case is only directly social if he makes known his resolution and thereby inevitably delegates some of his powers of self-discipline to his acquaintances - in so far as he values their opinion of his strength of character, and hence avoids their censure as well as his own. Less trivially, a person may dedicate himself or his possessions to his god. Even when privately performed, such a vow will generally have social consequences; but again, it is only directly social to the extent that priests or others, acting as representatives of the abstract entity to which the devotee has relinquished his autonomy, actually assume and exercise the powers that have been surrendered. In so far as these cases are less than directly social, I shall treat them as secondary applications of the idea, derivative from the social usage. The justification for doing so cannot be presented at length here. But the argument, in brief, would be that, on the one hand, both the internalised conception of the individual's moral personality (his 'self') and the idealised conception of the cultural group's religious personality (its 'god') are abstractions which arise out of, and are sustained by, processes of social interaction; while on the other, the basic mechanism by which individuals 'represent' cultural abstractions whether of individual or collective personality - to both themselves and others is universally implicated in all social processes, including those of 
alienation and appropriation. These examples, which resemble the social paradigm, yet where it would be eccentric to use the words 'alienation' and 'appropriation' in ordinary discourse, incidentally serve as a reminder that, linguistic though the discussion must be, it concerns concepts, not words.

'Estrangement' (Entfremdung, entfremden) - which I am substituting for the other English sense of 'alienation'-also seems to have a primary reference to social relationships. It denotes a process, or condition, by which people become or are strangers or enemies to one another. Usually, but perhaps not necessarily, its use implies a contrast with a previous state of solidarity. Certainly, for this sense of mutual estrangement, 'solidarity' denotes the opposite condition. Unlike the sense of 'alienation', just considered, which refers only to actions, not emotions, estrangement refers in the first place to how people feel about one another and describes the affective tone or texture of a relationship, or the direction in which its emotional content is changing. It is an incidental disadvantage of restricting the use of 'alienation' as I have, that 'estrangement' is rather milder in its emotional connotation than the sense of 'alienation' for which I am making it do duty. For 'estrangement' has as its core the idea of people treating each other as strangers, whereas 'alienation' includes this but also extends to the extremes of enmity. The sense of 'estrangement' being proposed here, therefore, will be extended to cover the normal range of 'alienation', part of the justification for this being that Entfremdung, in Hegel and Marx, has a similar extension. In taking the interpersonal process or state of estrangement as the primary reference, rather than actions, I am treating as secondary certain related transitive verb-forms. For instance, we might speak of a person's action estranging another from him, or of one person estranging two others who had been friends or married (or of one country's diplomacy 'alienating' another country from a third). All these refer to actions from the standpoint of their effects in 'cooling' or 'distancing' partners in a relationship, and can perhaps be regarded as secondary in the same sort of way as 'to cool' or 'to distance'-or for that matter, 'to heat' as in 'heating a room'-seem secondary to the concepts expressed in 'cool', 'distance' and 'hot'.

The basic sense of mutual estrangement refers to situations where there is matching of reciprocal orientations. People regard one another as strangers or enemies. These orientations are types of 'self-other' orientation, and as such have two aspects, affective and cognitive. The affective range, from indifference to hostility, has already been commented on. Although one cannot be too positive in an empirical matter, it may be suggested that the cognitive aspect has six linked elements. These are (i) whether the salient features of the other's identity are familiar or unfamiliar; (ii) if familiar, whether or not they are an object of hostility for self; (iii) depending on (i), whether his attitudes are known or unknown, and (iv) his behaviour predictable or unpredictable; $(v)$ whether his attitudes are likely to be 
hostile, and (vi) whether his behaviour is likely to be dangerous. With the aid of these variables one could construct pure types of strangerorientation and enemy-orientation. Others are treated as strangers to the extent that the salient features of their identity are unfamiliar, and hence their attitudes unknown, possibly hostile, and their behaviour unpredictable, possibly dangerous, and in any case dangerous merely by being unpredictable. Others are treated as enemies to the extent that salient traits of their identity are familiar and objects of hostility for self, and their attitudes also thereby known or presumed to be hostile; their behaviour is predictable only as being dangerous for being guided by malice. An intermediate type of orientation is that of persons who become estranged having been solidary. Here, newly salient and unfamiliar features of the other identities make them strangers to each other, but in addition, by disturbing the predictable basis of the old relationship, these features are dangerous in themselves, and all the more so if the other's new features are themselves objects of hostility for self, or his new attitudes known or thought to be hostile, or his new behaviour dangerous. Although the presentation of these types assumes interpersonal contexts, either or both of the parties may just as well be collectivities.

Obviously, orientations having cognitive aspects similar to these may exist which are not of the self-other type at all. Stranger and enemy orientations specify at the self-other level a general mode of defensive and offensive orientation which may relate to animals or inanimate things in so far as they are objects of hostility for self, or are seen as unfamiliar or dangerous. Such instances would fall outside the concept of 'estrangement', however. On the other hand, relationships of estrangement may be introjected, or projected upon ideational objects, so there are corresponding secondary uses to consider, whose relationship to the primary sense of mutual estrangement parallels the relationship to real alienation of alienative 'transactions' with internal or imaginary others. We might speak of 'self-estrangement', therefore, where one becomes a stranger to oneself, which resembles the case where unfamiliar features of identity emerge between intimates and estrange them from each other; or where one is one's own enemy. ${ }^{2}$ (For example, one's self may be partially in the power of a hostile other, so that one is self-active in self-destructive ways.) Secondly, there may be estrangement between a person (or people) and a god, whether their own or another's. ${ }^{3}$ As with alienation, so here this estrangement would only be directly social to the extent that it appeared as relationships of estrangement between persons whose salient identities were religious roles. A roughly similar point can be made about cases of estrangement between persons (or groups) and secular cultural entities, such as the state: the 'outlaw' is in a state of war with all or any who represent 'law'. To be distinguished from all these cases of mutual 'estrangement between' are cases of one-sided 'estrangement from' - whether from persons,'gods, authorities, the dominant culture, or 
'reality itself', etc. These are attitudes of individuals or groups which, in so far as they influence orientations in interaction, do have social consequences but cannot by themselves comprise the emotional texture of relationships. For the latter is always the resultant of two or more inputs. One-sided estrangement, therefore, in so far as it does not produce mutual estrangement, may contribute to relationships of misunderstanding, frustration, etc.

Hitherto the fact that English and French have one word for both the concepts which have been separated as alienation and estrangement has been treated as if it were no more than a coincidence. However, this etymological datum indicates an important semantic linkage between them. This is the association of ideas between what is strange or foreign, and what is 'other than' something else. This association turns into an equivalence of meaning where we are dealing with what is 'other than' the familiar, or 'other than' what is identified with the self and its extensions - which is the 'otherness' to which objects are consigned when they are alienated. Thus 'alien' in English can mean either 'foreign in nature' (i.e. strange) or 'belonging to another person, place or family'. The Latin root, alienus ('belonging to another') derives simply from alius ('other', 'another'). The same connection reappears in German, but in the reverse etymological direction: instead of the apparent association running from otherness to strangeness, it runs from strangeness to otherness. Thus the root of Entfremdung - i.e. fremd ('strange', 'foreign') - has the second meaning 'belonging to another or to others'. In this sense it is the antonym of eigen ('one's own', 'belonging to oneself'). In Marx, the relationship between Entfremdung and the eigen-fremd polarity (within which occur the processes of alienation and appropriation) is an important part of the theoretical problem. ${ }^{4}$

Obviously, strangeness is a much narrower and more concrete attribute than otherness, and they only tend to equate when we use 'alien' or 'foreign' to mean 'radically other' or 'other in essence' than something else. But what the two ideas have in common is that they qualify their object only by defining it negatively. What is other than $\mathrm{X}$ is simply not-X, and what is strange is merely not anything familiar, where the familiar is necessarily finite and known. The tendency to equate the terms, attested by etymology, is presumably due to the assumption, warranted in most practical contexts or where $\mathrm{X}$ is an existential predicate, that what is defined negatively by a property that it lacks is necessarily less familiar, finite or knowable than what is defined by possession of the property itself. It may not be so clear that cases where 'alien' and 'other' are commonly equated could also involve any notion of hostility or antagonism. However, just as the use of 'property' in the sentence before last indicates how the language of traditional logic contains metaphors drawn from the language of appropriation and alienation, so dialectical logic - from which our pregnant senses of 'alienation' arose-drew metaphors from the social 
processes of estrangement. The merely indifferent opposition of $\mathrm{X}$ and not$\mathrm{X}$ thus contained the possibility, which the dialectical process could convert into necessity, of developing into a contradiction and clash of irreconcilable opposites.

In this context a further semantic linkage comes to light. For what is defined as other than $\mathrm{X}$, and thereby alien or foreign to $\mathrm{X}$, is thus excluded from $\mathrm{X}$ and put outside its sphere. But this is almost exactly the root meaning of Veräusserung and Entäusserung, which unlike the Anglo-French 'alienation' comes from the root 'outside' (ausser). Thus to alienate something is also to exteriorise or externalise it, in a moral sense: to place it beyond one's control and exclude it from one's circle, or private area, by renouncing one's claims upon it. But equally, persons or groups that are estranged are, at the least, mutually excluding entities who, if they enter one another's spheres, can only trespass and encroach, as outsiders whose different interests become antagonistic by the mere fact of intrusion.

These semantic and etymological linkages, which help to make the concept of alienation such a resonant instrument in the hands of a dialectician, clearly derive much of their force from the usages of a society dominated by private ownership. For the concept to be useful in the scientific analysis of such a society, these connotative ambiguities would have to be purged, and the extent to which Marx achieved this is a measure of the sociological importance of his theory.

In this introduction, the two unit ideas of alienation and estrangement have been distinguished and delineated as sharply as is possible at this stage. Then some of their semantic interconnections, which inevitably blur the distinction, have been reintroduced. The further refinement and elaboration of these ideas as sociological concepts is taken up at the beginning of Part II. Part I, meanwhile, contains a historical discussion of the interplay of these two unit ideas in traditions of social theorising, up to and including the works of the young Marx. Readers who are already surfeited with such historical surveys, therefore, are advised to turn straight to Chapter 4 . 